DOT/FAA/AM-93/4

Office of Aviation Medicine

W'ashington, D.C. 20591

\title{
Contribution of Personality to the Prediction of Success in Initial Air Traffic Control Specialist Training
}

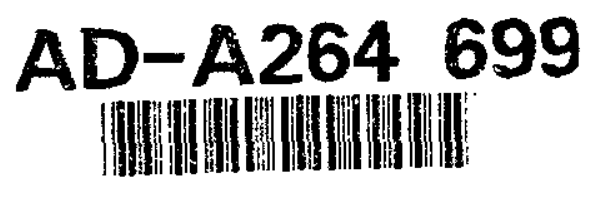

David J. Schroeder

Dana Broach

Willie C. Young

Civil Aeromedical Institute

Federal Aviation Administration

Oklahoma City, Oklahoma 73125

April 1993

Final Report

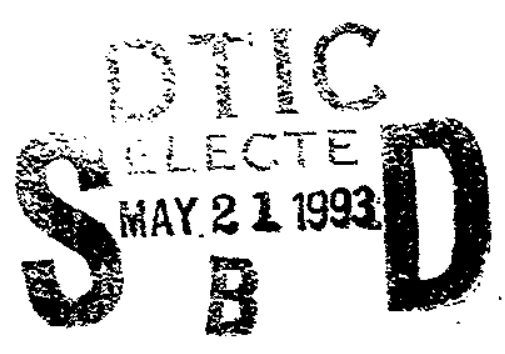

This document is available to the public

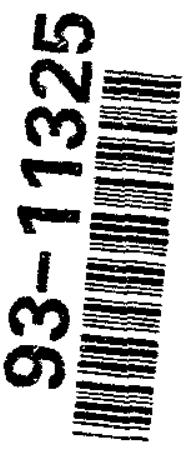
through the National Technical Information Service, Springfield, Virginia 22161.
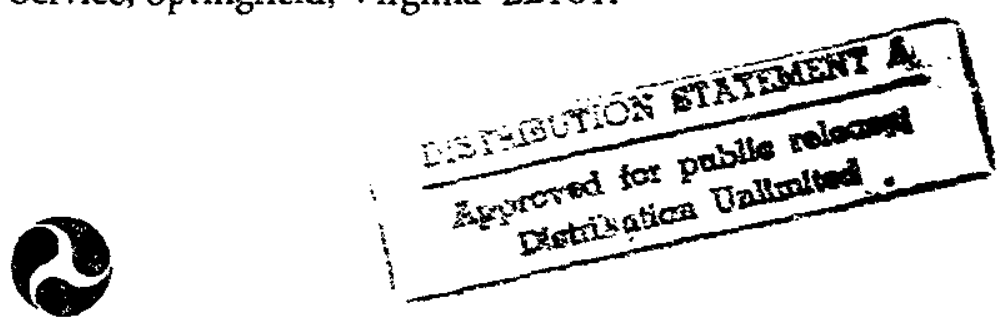

U.S. Departmeni of Transportation

Fecieral Aviation Adoministration 


\section{NOTICE}

This document is disseminated under the sponsorship of the U.S. Department of Transportation in the interest of information exchange. The United States Government assumes no liability for the contents or use thereof. 


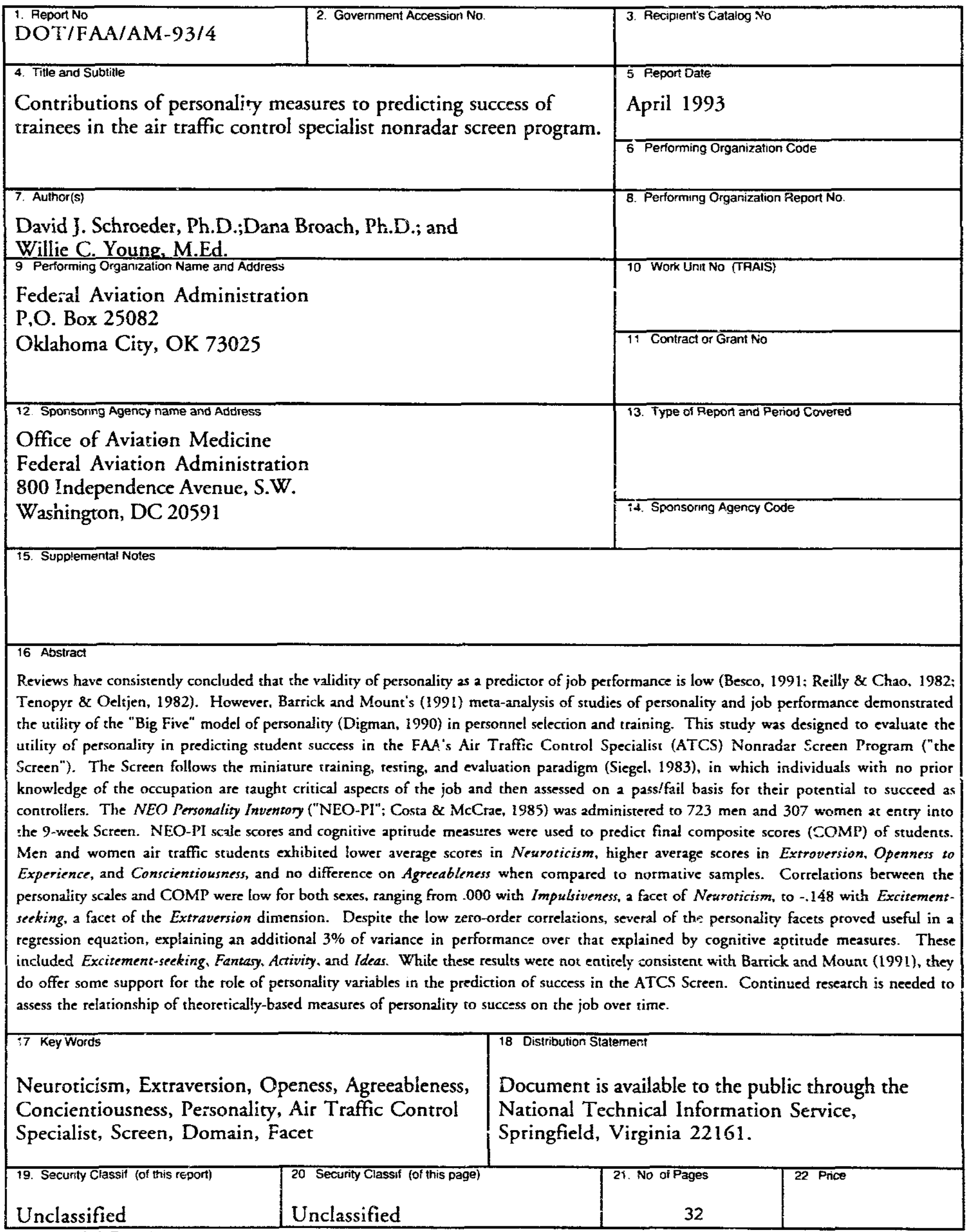

Form DOT F 1700.7 (8-72) Feproduction of completed page authorized




\section{ACKNOWLEDGMENTS}

The authors gratefully acknowledge the support for data collection provided by the FAA Academy during the course of this research. The opinions expressed in this report are those of the authors and do not necessarily represent official Federal Aviation Administration policy.

A version of this paper was previously presented at the 34th Annual Meeting of the Aerospace Medical Association, Miami, FL. 


\section{Contribution of Personality to the Prediction of Success in Initial Air Traffic Control Specialist Training}

The general public and the news media often ascribe personality characteristics to individuals in certain occupations. For example, the air traffic control specialist (ATCS) occupation is sometimes described in terms of personality traits such as "stress tolerant" and "attentive to detail." This ascription is sometimes extended to suggest that individuals with certain personality characteristics are attracted to specific occupations. Some research findings, such as that of Kasserz and Russo (1987), provide scientific support to this lay notion of convergence between personality and occupation. Personality is also cited as an explanation for occupational petfor. mance. For example, in a review of cognitive and noncognitive factors associated with ATCS performance, Colman (1970, p. 47) noted that the "importance of personality, interest, and motivation in successful performance of air traffic control work is recognized not only by the mental health staff of the agency, but by working controllers, supervisors, personnel and general medical specialists as well." This view that personality is related to occupational choice and performance suggests two basic research questions: (a) do persons who ente: the ATCS occupation differ from the general public with respect to general personality characteristics; and (b) what personality characteristics, if any, predict who is likely to become a successful controller?

\section{Previous Research}

\section{Differences Between Controllers and General Population}

Previous research is mixed on the question of personality differences between controllers and the general population. On one hand, Karson and O'Deil (1974) compared controllers $(N=11,074)$ and the general population using Cattell's 16PF. While most of the comparisons were statistically significant, the differences of practicai significance indicated that controllers were, on the average, brighter $(B)$, more conforming to the group $(G)$, tough minded $(I)$, practical $(M)$, self-disciplined $(Q 3)$, and less suspicious $(L)$ than the normative $16 \mathrm{PF}$ sample. Rose, Jenkins, and Hurst (1978) reported that results from administration of the $16 \mathrm{PF}$ to their sample of 388 controllers were highly similar to those noted by Karson and O'Dell. About 15 years later, Schroeder and Dollar (1989) found evidence of the same general 16PF profile for controllers $¥$ Sarson and O'Dell and Rose, et al. However, the 1984 applicant group $(\mathrm{N}=3,468)$ also reported less insecurity $(O)$, less tension $(Q 4)$, and greater self-assertiveness $(E)$, self-discipline $(Q 3)$, and emotional stability ( $C$ ) than the 1974 controller group. Similarly, Deloney and Schroeder (1984) found differences between entry level controllers $(N=4,244)$ enrolled in the FAA Academy and individuals in college or other occupational settings, using the Myers-Briggs Type Indicator (MBTI; Myers, 1962). There were higher percentages of controllers classified as Sensing-Thinking-Judging (ISTJ \& ESTJ) than among other groups.

On the other hand, Rose, Jenkins, and Hurst (1978) found little difference between controller scores $(N=$ 391 ) and population norms on the California Personality Inventory (CPI; Gough, 1960). In that study, controllers were lower on Socialization and Responsibility scales than the normative group, and low average on Self-control. but were still within normal limits. Air traffic controllers in the field, as well as in the Academy classroom, have also been consistertity reported as having lower levels of trait anxiety than individuals in other occupational groups (Collins, Schroeder, \& Nye, 1991; Nye \& Collins, 1991; Smith, 1985). In summary, there is some evidence that individuals attracted to the ATCS occupation differ from other, general population groups along at least some personality dimensions.

\section{Personality and Performance}

Studies finding no relationship. Several studies on the relationship of personality to ATCS training and on-thejob performance are consistent with influential reviews of the selection literature in aviation and other occupations which concluded that the validity of personality as a predictor of job performance is low, at best (Besco, 1991; Dolgin \& Gibt, 1989; Guion \& Gottier, 1965; Guion \& Gibson, 1988; Reilly \& Chao, 1982; Tenopyr \& Oltjean, 1982). For example, Colman (1970) described a study conducted by Karson and O'Dell (1969) that found little evidence of any significant relationship

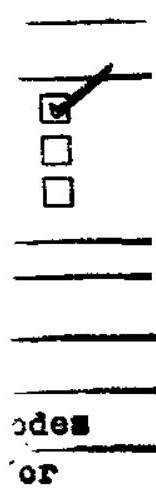


between scores on the $16 \mathrm{PF}$ and job performance ratings in the controller Employee Appraisal Record. Resedrch by Schroeder (1984) using Barrett's Impulsiven... viale and Manning (1984) using Zuckerman's (1979) Sensation Seeking Scale found little evidence for relations between those personality constructs and ATCS performance.

Studies finding some relationships. On the other hand, there are also several studies of controllers suggesting that there is a relationship between personality and ATCS performance. For example, Colman also cites work by Buckley, O'Connor, and Beebe (1969) in which statistically significant relationships between controller performance on an air traffic control simulation and 16 PF scores were reported for a very small sample of 36 controllers. More recently, Collins, Nye, and Schroeder (1991) found that although entry level controllers reported significantly lower leveis of anxiery on the StateTrait Personality Inventary (STPI; Speilberger, 1979), self-reported anxiety was still related to success in initial ATCS training. Individuals reporting higher leveis of borh state and trait anxiety experienced higher failure rates than those reporting lower levels of anxiety. In a study from the United Kingdom, Nyfield, Kandola, and Savilte (1983) obtained 58 significant correlations, ranging from .16 to $.31(N=112)$, between 32 Occupational Personality Questionnairescores (OPQ; Nyfield, Kandola, \& Saville, 1983) and 22 measures of ATCS job performance. Several of the correlations were related to technical proficiency (c.g., ability to form a mental picture from flight progress strips only). But a majority of the correlations were with assessments of controller relationships with orher personnel (e.g., cooperation from others, doesn't experience difficulty in relation to colleagues and supervisors). In Germany, the ATCS selection test battery inciudes personality dimensions such as Rigidity, Exiroversion, and Emotional Stability (Eissfeldt, 1990). The validity $(R)$ of the German bartery, including personality and cognitive dimensions, with various training performance criteria ranged from .51 to .61 with sample sizes of 162 to 196 entry-ievel controllers. Unfortunately, component standardized regression coefficients were not reported.

Critique of past research. At the time when most of the studies just reviewed were conducted, there was little consensus on an acceptable taxonomy for classifying personality traits in such a way as to determine if there were consistent, meaningful relationships between particular personality constructs and job performance measures across tests and actoss or within occupations (Mount \& Barrick, 1991). Recent meta-analyses of a large number of personality-oriented validation studies by Barrick and Mount (1991) and Tett, Jackson, and Rothstein (1991) demonstrated the utility of the "Big Five" model of personality in the prediction of various job performance criteria across many occupations. This model of personality suggests that there are five major factors of personality as described by factor and structural analyses of the domain of trait labels people use to describe themselves and others (Digman, 1990; Hofstee, 1984; Hogan, 1983; John, Angleitner, \& Ostendorf, 1988; Norman, 1963: Tupes \& Christal, 1961) Tett, et al., obtained a corrected estimate of the overall relation between "Big Five" personality dimensions and job performance measures of 24 , indicating that personality may have utility in the prediction of job performance. This line of research on the validity and urility of the "Big Five" model of personality is extended to the ATCS occupation in this study. Our specific purposes were (a) to investigate the differences, if any, between entry-level controllers and normative samples, and (b) to assess the incremental validity of a "Big Five" measure of personality over cognitive aptitude in the prediction of performance in initial ATCS training at the FAA Academy.

\section{METHOD}

\section{Sample}

Subjects for this study were drawn from students enrolled in the FAA Academy ATCS Nonradar Screen program between September, 1990 and May, 1991. Complete personality, aptitude, and training performance data were obtained for a total of 1,121 first-time entrants. Sample demographic characteristics are presented in Table I in comparison to the population of FAA Academy entrants. The sample was composed mostly of non-minority men with some college education with an average age of 26 (tange from 18 to 32 ); the majority reported some college education. As shown in Table 1, this sample of entry-level controllers was typical of the population of Academy entrants. 


\section{Table 1}

\section{Sample and Population Demographic Characteristics of ATCS Students}

\begin{tabular}{|c|c|c|c|}
\hline Characteristic & Category & $\begin{array}{l}\text { Population } \\
(N=9,945)\end{array}$ & $\begin{array}{c}\text { Sample } \\
(N=1,091)\end{array}$ \\
\hline Sex & $\begin{array}{l}\text { Men } \\
\text { Women } \\
\text { Missing }\end{array}$ & $\begin{array}{l}81.1 \%(8,065) \\
18.9 \%(1,880)\end{array}$ & 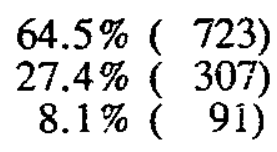 \\
\hline Ethnicity & $\begin{array}{l}\text { White } \\
\text { Asian } \\
\text { Native American } \\
\text { African American } \\
\text { Hispanic Non-white } \\
\text { Unknown }\end{array}$ & 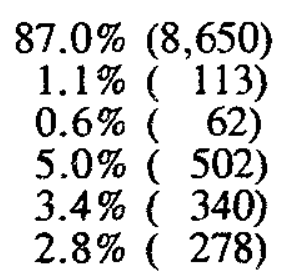 & 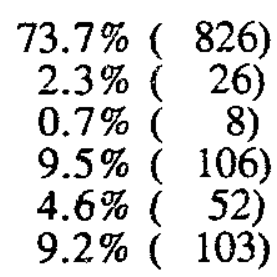 \\
\hline Age & $\begin{array}{l}\text { Mean } \\
\text { SD }\end{array}$ & $\begin{array}{c}26.1 \\
4.9\end{array}$ & $\begin{array}{r}26.3 \\
3.0\end{array}$ \\
\hline
\end{tabular}

\section{Measures}

The NEO Personality Inventory

The NEU Personality Inventory (NEO-PI; Costa \& $\mathrm{McCrae}, 1985$ ) is one of the first personality inventories designed to explicitly assess the five major personality dimensions identified over the course of more than 50 years of factor analytic research. The NEO-PI was developed through a series of overlapping factor analyses, longitudinal studies, and peer rating studies, using samples of aduit men and women rather than just college students. This research program is described by Costa and McCrae (1985; 1987, 1988a). The normative samples consisted of $502 \mathrm{men}$, ranging in ages from 21 to 93 , and 481 women, aged 19 to 93 . Estimates for coefficients of reliability for the scales range from .85 to .93 ; those for test-retest reliability range from .86 to .91 (Costa $\&$ McCrae, 1985, 1988b). The five primary scales comprising the NEO-PI are: Neuroticism $(N)$; Extraversion $(E)$; Openness to experience $(O)$; Agreeableness $(A)$; and Conscientiousness ( $C$ ). Each of the $N, E$, and $O$ domain scales are composed of six subscales assessing specific facets of each domain. As a result, meaningful individual differences can be seen within domains, providing a more fine- graincd analysis of persons or groups. Domain and facet scales descriptions are presented in Table 2.

\section{Aptizude}

A written aptitude test is administere 1 by the U.S. Office of Personnel Management (OPM) as the first hurdle to entering the ATCS occupation. The OPM ATCS written civil service examination battery is composed of three tests: (a) the Multiplex Controller Aptitude Test (MCAT); (b) a test of Abstract Reasoning (ABSR); and (c) an Occupational Knowledge Test (OKT). The general development, psychometric characteristics, and validity of this test battery are described by Sells, Dailey, and Pickrel (1984). Extensive research conducted by the Civil Aeromedical Institute indicates that scores on the civil service test battery are significantly correlated with student performance in the FAA Academy ATCS Screen program (Manning, Della Rocco, \& Bryant, 1989; Rock, Dailey, Ozur, Boone, \& Pickerel. 1981). Results from the test battery are combined with any statutory veteran's preference to yield a final civil service rating (RATING). This rating is used to rank-order ATCS job applicants 
within statutory guidelines such that hiring is done on the basis of merit, as more fully described in Aul (1991).

\section{Criterion}

The FAA Academy Nonradar Screen. The FAA Academy Nonradar Screen ("the Screen") was established in response to recommendations made by the U.S. 94th Congress House Committee on Government Operations (U.S. Congress, 1976) to reduce field training attrition rates. The most recent version of the Screen was implemented in October 1985, supplanting predecessor, option-specific (Terminal and En Route) programs in place from 1976 through 1985. This Screen was revised again in 1986, shortening the course from 60 to 42 working days; trie program remained relatively stable in content and process until it was terminated in March, 1992. The $S_{c r e e n}$ was based upon a miniaturized training-testing-evaluation personnel selection model (Siegel, 1978, 1983; Siegel \& Bergman, 1975) in which individuals with no prior knowledge of the occupation could be assessed for their potential to succeed in air traffic control.

Performance measures. The Screen was developed with a clear emphasis on the assessment of developmental performance using multiple methods (Boone, 1984). As a result, thirteen assessments of performance were made during the Screen (Deilz Rocco, Manning, \& Wing, 1990). These measures were derived from tests administered in the classroom, observed performance during laboratory simulations of non-radar air traffic control, and a final written examination. The measures were summed and weighted to create a final composite Screen score (COMP), ranging from a theoretical minimum of 12 to a maximum of 100 . A minimum score of 70 was required to pass the Screen. Failure in the Screen resulted in the removal of the student from the ATCS occupational series at the very least, and often in termination from employment with the FAA. The final composite score (COMP) was the training performance criterion of interest in this study.

\section{Procedure}

\section{Comparison to norms}

Three analytic procedures were employed to explore possible differences berween persons entering the ATCS cccupation and the general population. First, mean scores for the sample of entry-level controllers on the main and facet scales of the NEO-PI were compared with the published norms. The null nypothesis that there were no differences between entry-level controllers and normative groups was tested by $t$ test computed on the pooled variances of the groups. The overall risk of Type I errors across the multiple comparisons was minimized through the use of an unordered Bonferorni procedure (Rosenthal \& Rubin, 1984). The corrected criterion $\alpha$ for any given $t$ test was .004 , based on 12 comparisons for each sex. Second, mean differences were translated into Common Langiage Effect Sizes ( $C L ;$ MicGraw \& Wong, 1992) as an aid to clarifying the practical significance of any differences. The $C L$ metric for effect size is the number of times out of 100 that a randomly sampled entry level controller (group 1) will have a higher score on a given personality scale than a randomly sampled person from the general (normative) population (group 2). For example, if $C L=68$ with respect to the Extraversion domain scale of the NEO-PI, we would expect that, for any random pairing of a controller with a member of the general normative population, the controller would have the higher score 2 out of 3 times. A CL of 50 suggests that compared to a normative sample controllers would be no more likely to have higher scores on a scale than might be expected by chance alone. The third analytic procedure illustrates these mean differences and effect sizes in terms of the degree or percent of overlap in the distribution of scale scores for the controllers and normative groups. The greater the amount of overlap, as indicated by Tilton's $O(1937)$ statistic, the less effective a scale is in separating or discriminating between the two distributions. Taken together, these three analytic procedures provided information about potential differences between entry-level controllers and members of the normative populations. 
Table 2

NEO-PI Domain and Facet Scale Interpretations

Low Scores

Scale

High Scores

Calm, stable, relaxed, secure, deliberate

Relaxed, calm Amiable, even-tempered Hopeful, feels worthwhile Secure, comfortable

Self-controlled

Resilient, hardy

Reserved, aloof, quiet, reticent

Cold, formal

Solitary, self-contained

Unassuming, retiring

Slow, deliberate

Cautious, staid

Unenthusiastic, serious

Unlearned, realistic, pragmatic, dogmatic

Realistic, practical Insensitive to art and beauty

Narrow range of emotions

Prefers familiar, routine

Pragmatic, factual

Dogmatic, conservative

Cynical, rude, ruthless, uncooperative

Unreliable, disorganized, negligent
NEUROTICISM (N)

Anxiety (N1)

Hostility (N2)

Depression (N3)

Self-consciousness (N4)

Impulsiveness (N5)

Vulnerability (N6)

EXTRAVERSION (E)

Warmth (E1)

Gregariousness (E2)

Assertiveness (E3)

Activity (E4)

Excitement-seeking (E5)

Positive Emotions (E6)
Worried, tense, unstable, nervous, impulsive

Fearful, worried Angry, easily-frustrated Guilty, hopeless Ashamed, easily embarrassed Impulsive, unable to resist Intolerant of stress

Outgoing, gregarious, talkative, energetic

Talkative, affectionate Convivial

Dominant, forceful Energetic, vigorous

Flashy, takes risks

Cheerful, high-spirited
OPENNESS TO EXPERIENCE (O) Inquiring, analytical, tolerant, curious
Fantasy (OI)
Aesthetics (O2)
Feelings (O3)
Actions (O4)
Ideas (05)
Values (06)

AGREEABLENESS (A)

CONSCIENTIOUSNESS (C)

Organized, reliable, punctual, obedient 
Table 2

NEO-PI Domain and Facet Scdle Interpretations

Low Scores

Scale

High Scores

Calm, stable, relaxed, secure, deliberate

Relaxed, calm Amiable, even-tempered Hopeful, feels worthwhile Secure, comfortable

Self-controlled

Resilient, hardy

Reserved, aloof, quiet, reticent

Cold, formal

Solitary, self-contained

Unassuming, retiring

Slow, deliberate

Cautious, staid

Unenthusiastic, serious

Unlearned, realistic, pragmatic, dogmatic

Realistic, practical Insensitive to art and beauty

Narrow range of emotions

Prefers familiar, routine

Pragmatic, factual

Dogmatic, conservative

Cynical, rude, ruthless, uncooperative

Unreliable, disorganized, negligent
NEUROTICISM (N)

Anxiety (N1)

Hostility (N2)

Depression (N3)

Self-consciousness (N4)

Impulsiveness (N5)

Vulnerability (N6)

EXTRAVERSION (E)

Warmth (E1)

Gregariousness (E2)

Assertiveness (E3)

Activity (E4)

Excitement-seeking (E5)

Positive Emotions (E6)
Worried, tense, unstable, nervous, impulsive

Fearful, worried Angry, easily-frustrated Guilty, hopeless Ashamed, easily embarrassed Impulsive, unable to resist Intolerant of stress

Outgoing, gregarious, talkative, energetic

Talkative, affectionate

Convivial

Dominant, forceful

Energetic, vigorous

Flashy, takes risks

Cheerful, high-spirited
OPENNESS TO EXPERIENCE (O) Inquiring, analytical, tolerant, curious
Fantasy (OI)
Aesthetics (O2)
Feelings (O3)
Actions (04)
Ideas (O5)
Values (06)

AGREEABLENESS (Ä)

(A) Trusting, helpful, forgiving, gullible

Imaginative

Moved by art and beauty

Empathic, values feelings

Prefers new, novel

Curious, analytical

Tolerant, non-conforming

Organized, reliable, punctual, obedient 


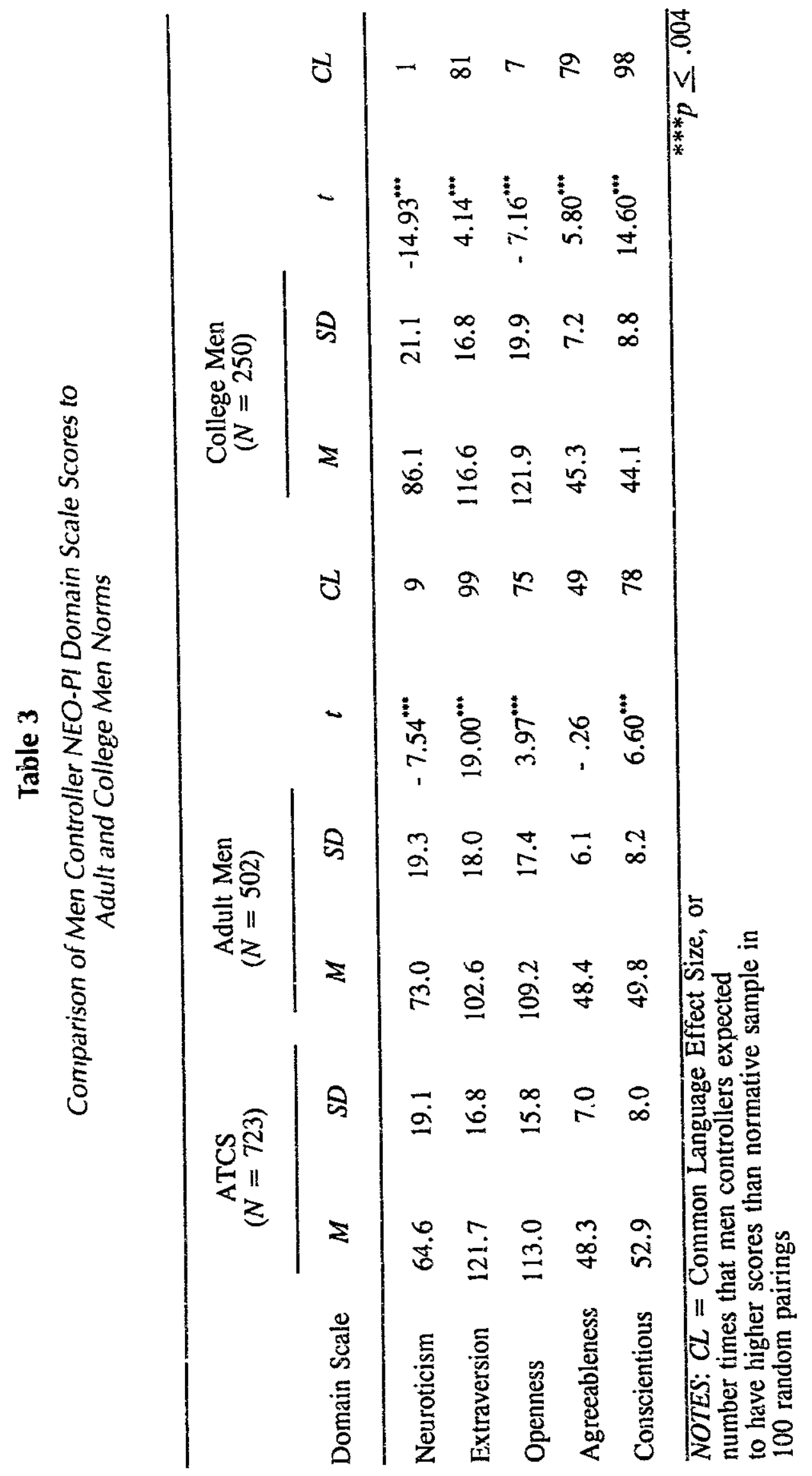




\section{Prediction of performance}

Zero-order correlations between the final OPM rating at hire (RATING), personality facet and domain scale scores, and final Screen composite score (COMP) were computed. These correlations were not corrected for direct and incidental restriction in range due to seiection of subjects on the OPM rating at hire. Therefore, the estimates from this analysis represent lower-bound estimates of the relationships between aptitude, personality, and performance in the general population. Blockwise multiple regression analysis was used to assess the incremental validity of the personality scales over that of the aptitude measure in the prediction of performance in the FAA Academy ATCS Screen program. The OPM rating at hire was entered into the regression equation in the first block in o:der to identify the proportion of variance in Screen performance accounted by cognitive aptitude. The personality $N, E$, and $O$ facet scales and $A$ and $C$ domain scales were examined in the second block using stepwise regression. Use of this procedure provided an assessment of the additional significant variance in Screen performance accounted for by personality beyond that already accounted for by the general cognitive aptitude measure. The null hypothesis was that personality measures would not account for additional variance in Screen performance beyond that accounted for OPM rating-

\section{RESULTS}

\section{Comparison to norms}

Men

Domain scales. Means and standard deviations for the NEO-PI domain scale scores for the men ATCS students, aduit men, and college nnen are presented in Table 3. While there appeared to be some degree of overlap between entry-level controllers and both adult and college men normative distributions (Table 4), the $t$ tests and $C L$ effect sizes, using a criterion of $C L \leq 25$ or $\geq 75$, indicated important differences between the groups in the overall profiles. ATCSs differed significantly from adult men on 4 of the 5 domain scales (all except Agreeableness) and from college men on each of the domains. As a group, ATCSs reported : "ficantly lower $(p \leq .004)$ neuroticism than the aduit or college men. The $C I$ suggest that 9 or fewer entry-level controllers might be expected to have higher $N$ scores then normative adult or college men in 100 random pairings. ATCSs were also more extroverted and conscientious than either adult men or college men, with far more controllers expected to have higher $E$ and $C$ scores than normative men in 100 random pairings.

On the Openness to Experience dimension, ATCSs had higher scores than adult men $(p \leq .004)$ but lower than

\section{Table 4}

Percentage Overlap (Tilton's O) in Controller and Normative Distributions for Men on NEO-PI Domain Scales

\begin{tabular}{lcc}
\hline Domain Scale & $\begin{array}{c}\text { Overlap of ATCS Men with } \\
\text { College Men } \\
(N=502)\end{array}$ & $\begin{array}{l}\text { Adult }=250) \\
\text { Neuroticism }\end{array}$ \\
Extraversion & $82 \%$ & $59 \%$ \\
Openness & $56 \%$ & $88 \%$ \\
Agreeableness & $91 \%$ & $90 \%$ \\
Conscientiousness & $99 \%$ & $83 \%$ \\
\hline
\end{tabular}




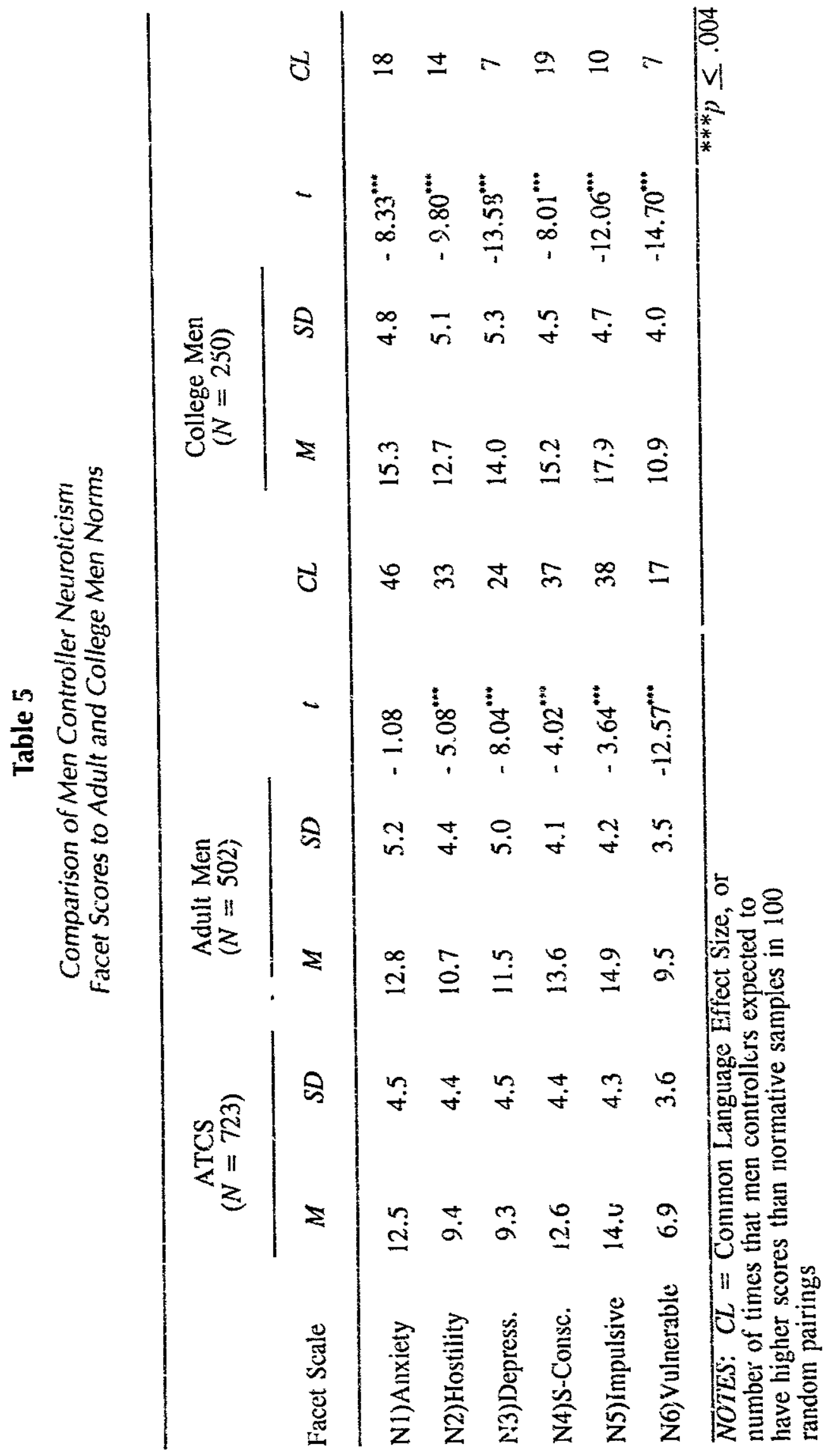




\author{
Table 6 \\ Percentage Overlap (Tilton's O) in Controller \\ and Normative Distributions for Men on NEO-Pl Facet Scales
}

\begin{tabular}{ccc}
\hline & $\begin{array}{c}\text { Overlap of Men ATCS Students with } \\
\text { Adult Men } \\
(N=502)\end{array}$ & $(N=250)$ \\
\hline
\end{tabular}

NEUROTICISM

$\begin{array}{lll}\text { Anxiety } & 96 \% & 76 \% \\ \text { Hostility } & 88 \% & 73 \% \\ \text { Depression } & 82 \% & 62 \% \\ \text { Self-Consciousness } & 90 \% & 77 \% \\ \text { Impulsiveness } & 91 \% & 66 \% \\ \text { Vulnerability } & 71 \% & 60 \%\end{array}$

\title{
EXTRAVERSION
}

Warmth

Gregariousness

Assertiveness

Activity

Excitement-Seeking

Positive Emotions
$86 \%$

$77 \%$

$81 \%$

$73 \%$

$46 \%$

$68 \%$

OPENNESS

Fantasy

Aesthetics

Feelings

Actions

Ideas

Values
$94 \%$

$93 \%$

$88 \%$

$95 \%$

$80 \%$

$97 \%$
$86 \%$

$99 \%$

$79 \%$

$87 \%$

$99 \%$

$100 \%$

$70 \%$

$74 \%$

$83 \%$

$68 \%$

$89 \%$

$94 \%$ college men $(p \leq .604)$. Average ATCS scores on the $A$ scale did not differ from those of adult men but were higher than those of college men $(p \leq .004)$.

Facet scales. Comparisons of the average ATCS men's scores on the $6 N$ facet scales with those of the two normative groups appear in Table 5, with overlap in distributions presented in Table 6. The pattern of scores for the three groups was consistent on each of the 6 facets, except for Anxiety. That was the only facet on which scores for ATCS men and adult men did not significantly differ. Otherwise, college men had generally higher average scores on the $N$ facets, adut men were in the middle, and men controllers had lower average scores. As shown in Table 6, there was less overlap between entrylevel controller and college men distributions than with aduit men. Means, standard deviations, results of the $t$ tests and CL estimates for the three men's groups on the 6 Efacet subscales are presented in Table 7. Mean scores for men controllers were significantly higher than for adult men on each of the six $E$ facets $(p \leq .004)$. However, controllers differed from their college counterparts on only the Warmth, Assertiveness, and Activity facets, with controllers presencing higher mean scores. Overall, the effect sizes in Table 7 and overlap indices presented in 


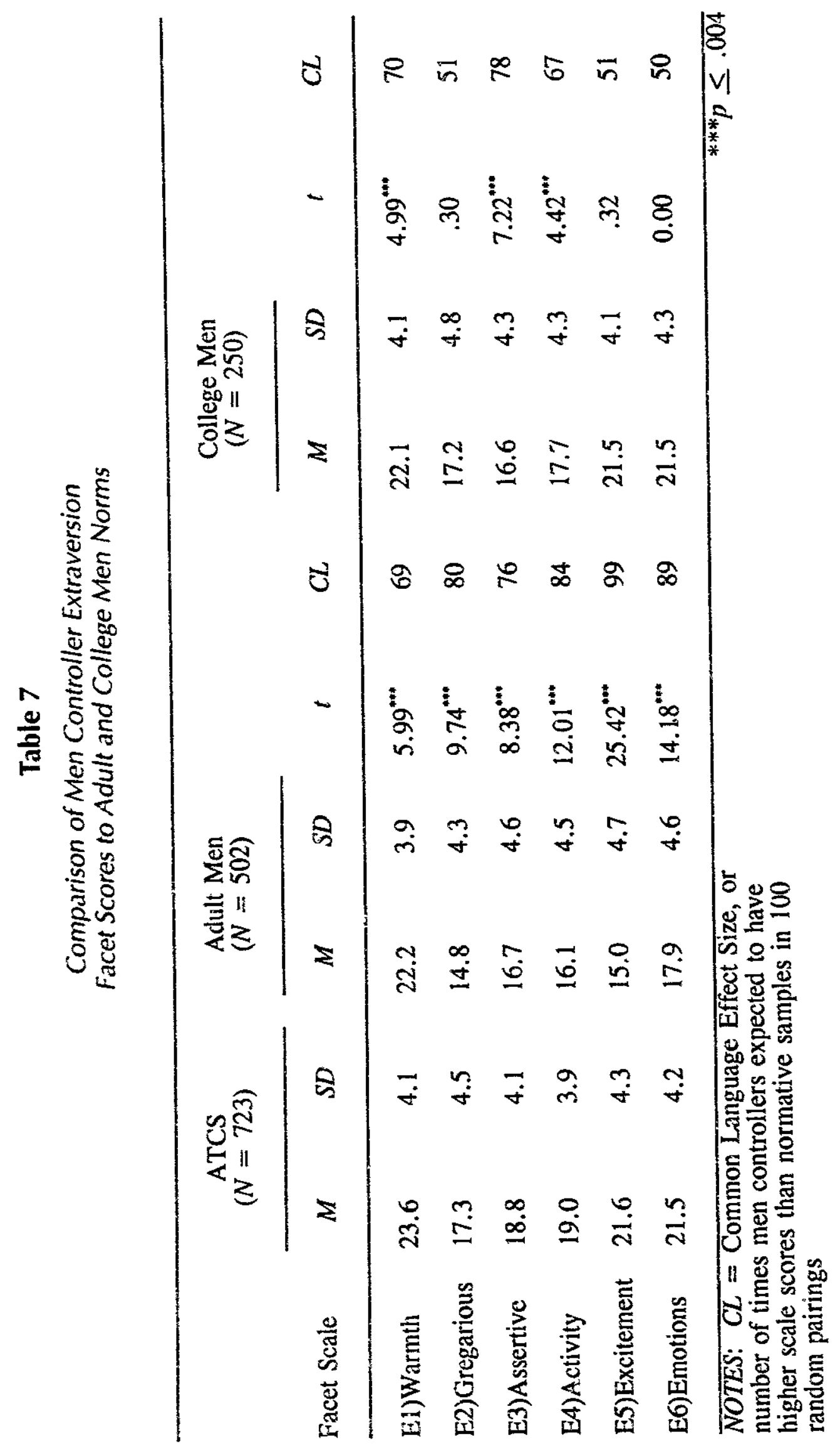




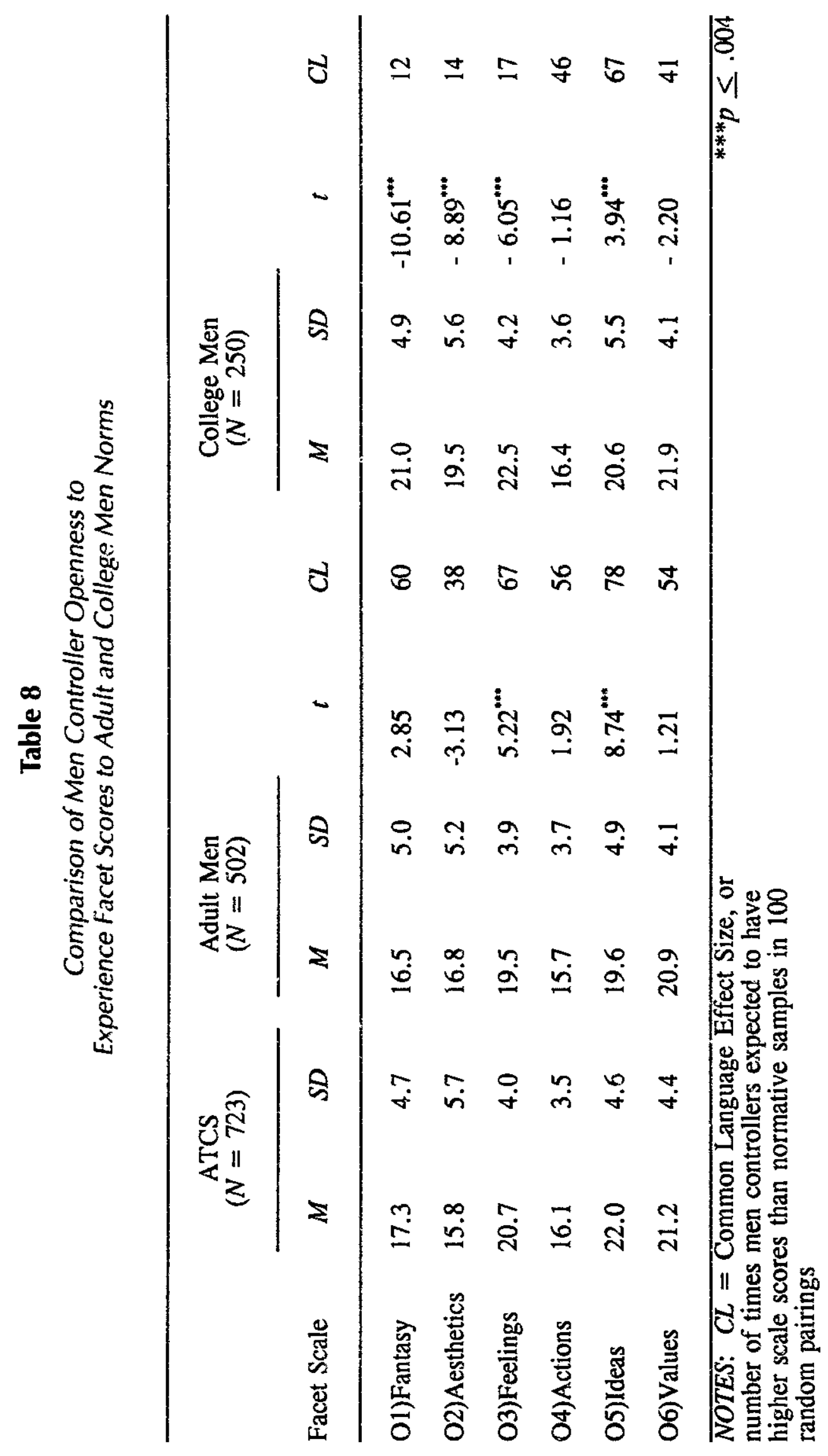




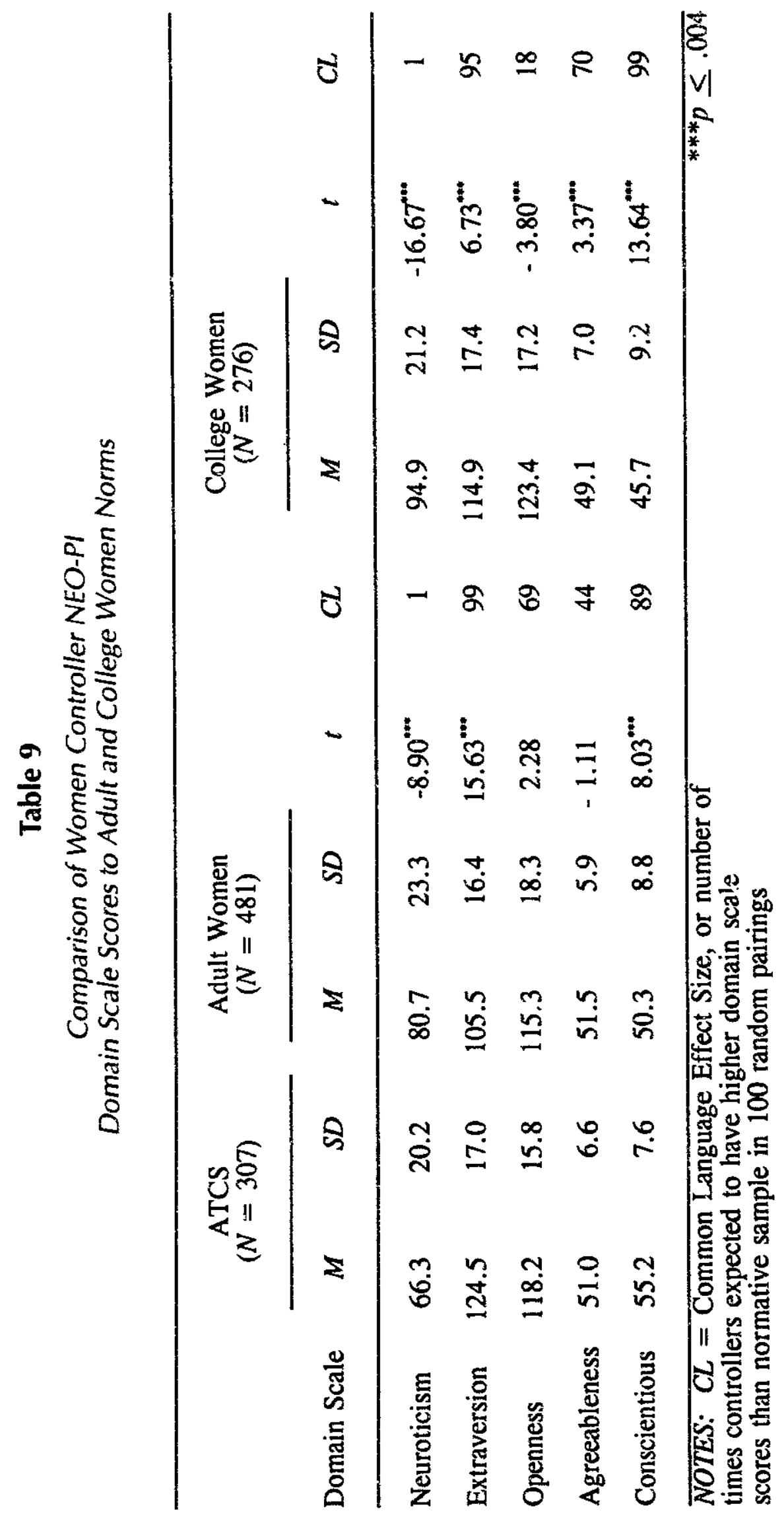


Table 10

Percentage Overlap (Tilton's $O$ ) in Controller and Normative Distributions for Women on NEO-PI Domain Scales

\begin{tabular}{lcc}
\hline Domain Scale & $\begin{array}{c}\text { Overiap of Women ATCS Students with } \\
\text { Adult Women } \\
(N=481)\end{array}$ & $\begin{array}{c}\text { College Women } \\
(N=276)\end{array}$ \\
\hline Neuroticism & $74 \%$ & $49 \%$ \\
Extraversion & $57 \%$ & $78 \%$ \\
Openness & $93 \%$ & $87 \%$ \\
Agreeableness & $97 \%$ & $89 \%$ \\
Conscientiousness & $77 \%$ & $57 \%$ \\
\hline
\end{tabular}

Table 6 suggested that entry-ievel controllers were more similar to college men in the $E$ domain than to adult men. Means, standard deviations, $t$ tests, and $C L$ estimates for the $O$ facet subscales are presented in Table 8 . Average scores for ATCS men were significantly higher than those of adult men on the Feelings $(p \leq .004)$ and Ideas $(p \leq .004)$ facets. Men controllers differed significantly from college men on each of the $O$ facets except Actions and Values. Compared to the ATCS men, college men were higher on Fantasy, Aesthetics, and Feelings, but lower on Ideas. Overall, the pattern of $C L$ effect size estimates and overlap in distributions suggested that entry-level controllers were more similar to adult men in terms of their openness to experience than they were to college men.

\section{Women}

Domain scales. Comparisons of the means and standard deviations for women ATCSs, adult women, and college women on the 5 NEO-PI domains appear in Table 9. Estimates of the degree of overlap between controller and normative score distributions are presented in Table 10 for the domain scales. Scores for ATCS women differed significantly from those of adult women on 3 of the 5 dimensions and from college women on each of the
5 dimensions. Women entry controliers did not differ from adult women on the Agreeableness and Openness domain scales. In comparison to adult women, ATCSs reported less neuroticism and greater extraversion, openness, and conscientiousness. They also appeared to have less neuroticism and openness than college women. Wornen ATCSs were more extraverted and exhibited higher agreeableness and conscientiousness scores than did their college counterparts. Overall, the pattern of effect sizes and degree of overlap between distributions (Table 10) suggested that entry-level women controllers were more similar to adult women than they were to college-aged women.

Facet scales. Table 11 presents the means, standard deviations and $t$ test comparisons for the three groups on the 6 Neuroticism facet subscales. ATCS women had significantly lower scores $(p \leq .004)$ than either adult women or college women on 5 of the $6 \mathrm{Nfacats}$; women controllers and adult women did not differ on the Impulsive facet. The pattern of scores for the three groups was similar to that noted for men, ATCS women had the lowest scores, adult women were in berween, and college women had the highest scores. Overall, the pattern of overlap between distributions (Table 12) and $C L$ effect sizes suggested that entry-level women controllers were 


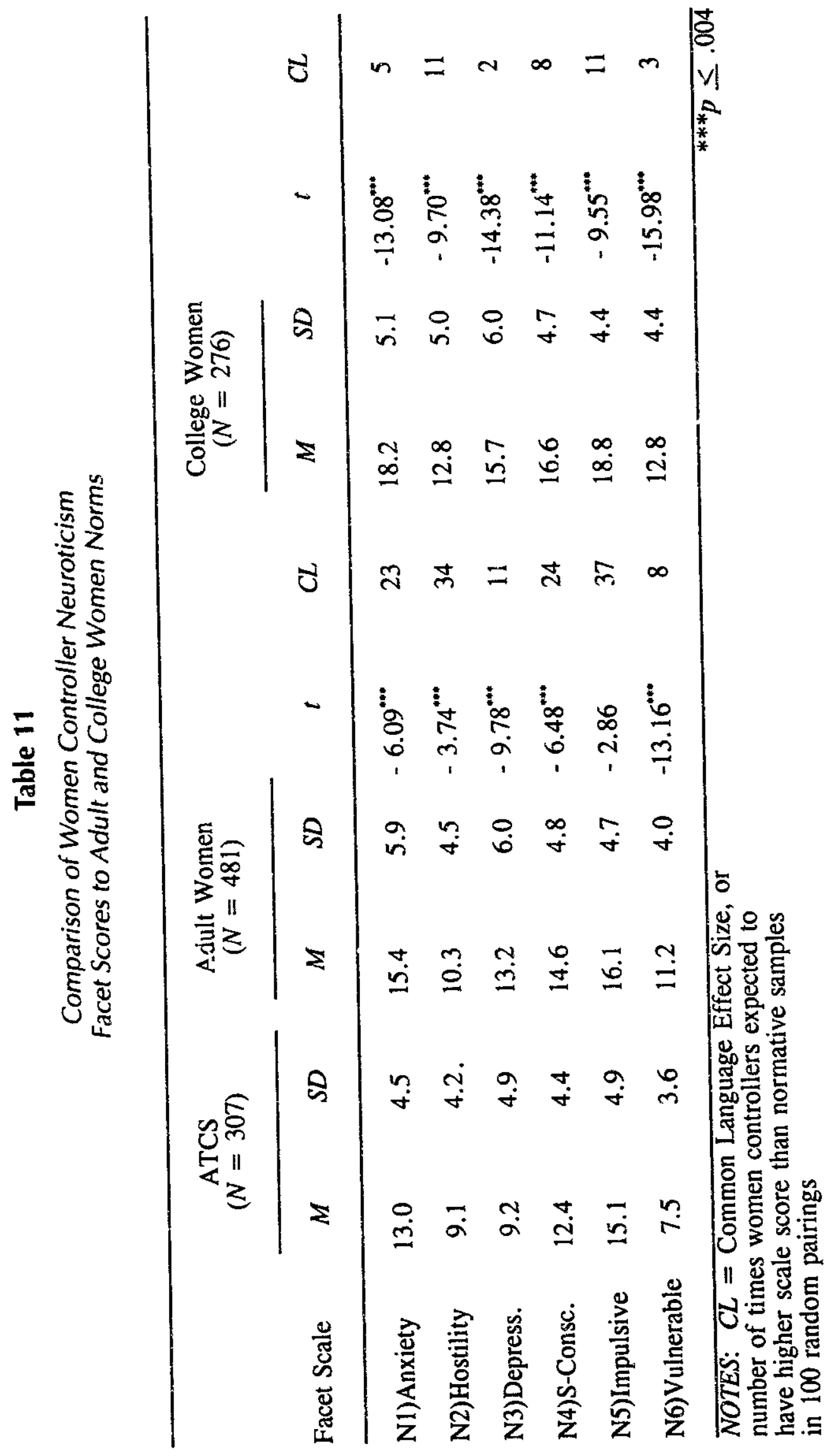


Table 12

Percentage Overlap (Tilton's $O$ ) in Controller and Normative Distributions for Women on NEO-PI Facet Scales

\begin{tabular}{lcc}
\hline Facet Scale & $\begin{array}{c}\text { Overlap of ATCS Women with } \\
(N=481)\end{array}$ & $\begin{array}{c}\text { College Women } \\
(N=276)\end{array}$ \\
\hline
\end{tabular}

\section{NEUROTICISM}

Anxiety
Hostility
Depression
Self-Consciousness
Impulsiveness
Vulnerability

Warmth

Gregariousness

Assertiveness

Activity

Excitement-Seeking

Positive Emotions

$82 \%$
$89 \%$
$71 \%$
$81 \%$
$91 \%$
$63 \%$

\section{EXTRAVERSION}

$92 \%$

$82 \%$

$76 \%$

$75 \%$

$41 \%$

$72 \%$

\section{OPENNESS}

Fantasy

Aesthetics

Feelings

Actions

Ideas

Values
$98 \%$

$86 \%$

$93 \%$

$88 \%$

$78 \%$

$87 \%$
$59 \%$

$68 \%$

$55 \%$

$64 \%$

$84 \%$

$51 \%$
$78 \%$

$98 \%$

$71 \%$

$79 \%$

$99 \%$

$88 \%$ more similar to adult women in terms of the $N$ domain and its facets than they were to college women. Comparisons of the means and standard deviations for the three women groups on the Extraversion facet subscales are presented in Table 13. Average scores for women ATCSs were significantly higher than those of the adult women on 5 of the $6 E$ facet subscales and higher than those of college women on 4 of the 6 subscales. The largest mean difference occurred on the Excitement-seeking (E5) subscale (20.3 for ATCSs versus 12.9 for adult women); women controllers would be expected to have higher E5 scores than aduit women in 99 out of 100 random pairings. In general, the pattern of overlap between controller and normative sample distributions on the $E$ facet scales (Table 12) suggested that women controllers were more similar to college women than adult women in terms of their extraversion. Finally, facet scores for the $O$ domain subscales are compared in Table 14. Women controllers had significantly higher scores than adult women on the Ideas and Values facets. The CL effect size estimates indicated that, on the average, women controllers would be expected to have higher scores on these facets than would adult women. On the other hand, women controllers would be expected to have lower 


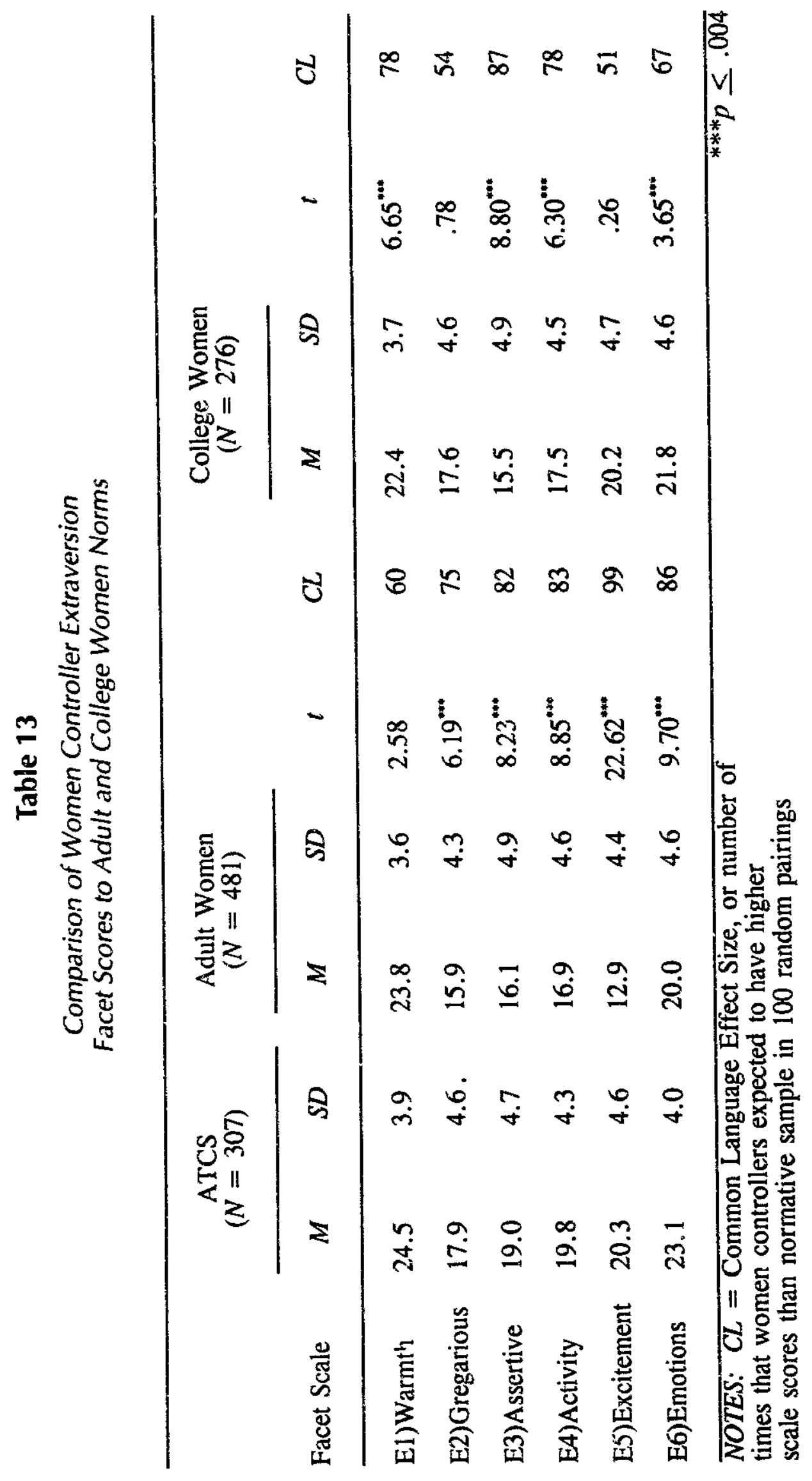




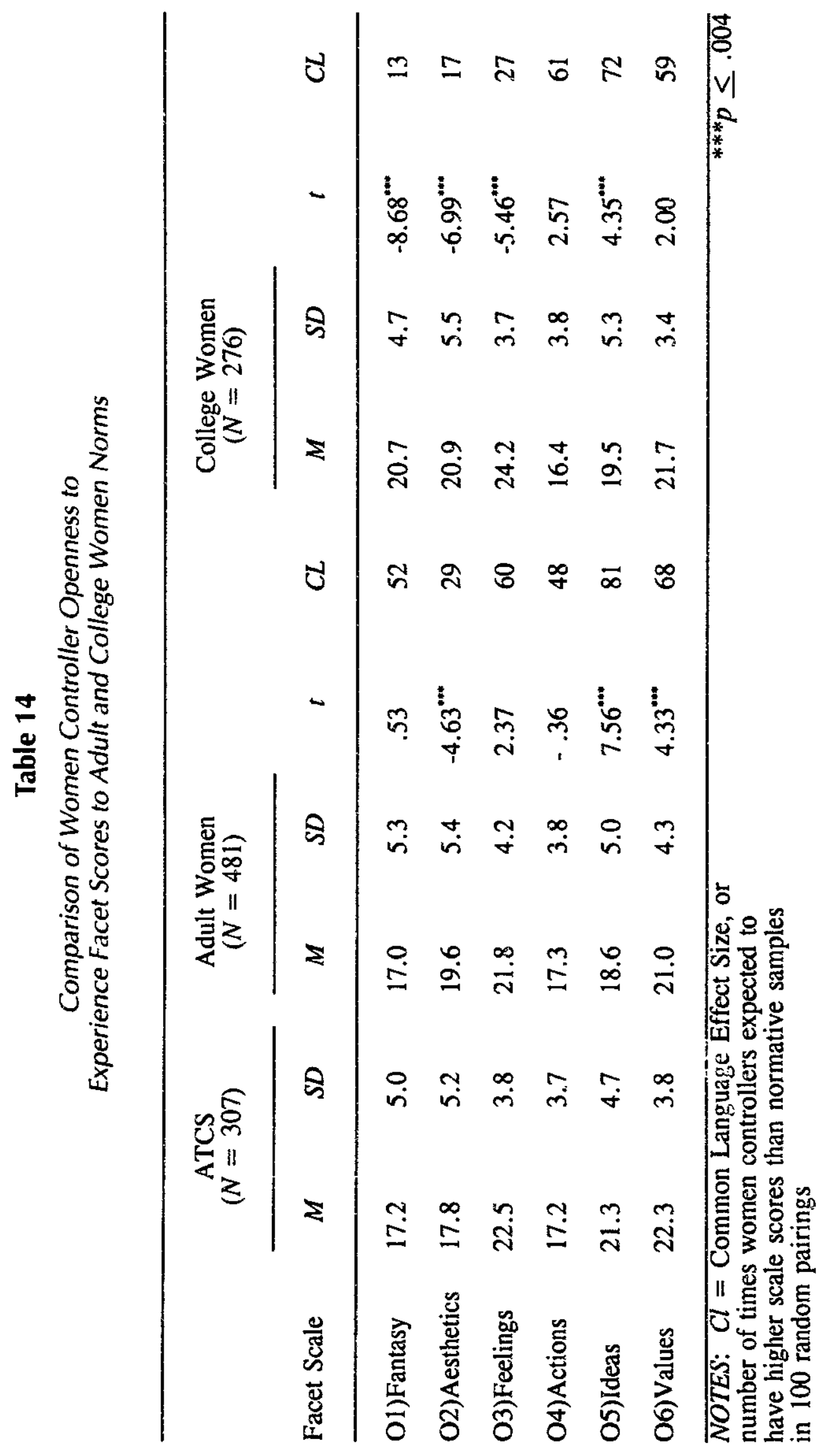


Table 15

NEO-Pi Domain and Facet Scale Scores for Controllers by Sex

\begin{tabular}{|c|c|c|c|c|c|c|}
\hline \multirow[b]{2}{*}{ DOMAIN/Facet Scale } & \multicolumn{2}{|c|}{$\begin{array}{l}\text { Male ATCS } \\
(N=723)\end{array}$} & \multicolumn{2}{|c|}{$\begin{array}{c}\text { Femaie ATCS } \\
(N=307)\end{array}$} & \multirow[b]{2}{*}{$t$} & \multirow[b]{2}{*}{$C I$} \\
\hline & $M$ & $S D$ & $M$ & $S D$ & & \\
\hline $\begin{array}{l}\text { NEUROTICISM } \\
\text { N1)Anxiety } \\
\text { N2)Hostility } \\
\text { N3)Depression } \\
\text { N4)Self-consciousness } \\
\text { N5)Impulisve } \\
\text { N6) Vulnerability }\end{array}$ & $\begin{array}{r}64.6 \\
12.5 \\
9.4 \\
9.3 \\
12.6 \\
14.0 \\
6.9\end{array}$ & $\begin{array}{r}19.1 \\
4.5 \\
4.4 \\
4.5 \\
4.4 \\
4.3 \\
3.6\end{array}$ & $\begin{array}{r}66.3 \\
13.0 \\
9.1 \\
9.2 \\
12.4 \\
15.1 \\
7.5\end{array}$ & $\begin{array}{r}20.2 \\
4.5 \\
4.2 \\
4.9 \\
4.4 \\
4.9 \\
3.6\end{array}$ & $\begin{array}{l}-1.28 \\
-1.63 \\
1.01 \\
0.32 \\
0.67 \\
-3.60^{* \cdots} \\
-2.45\end{array}$ & $\begin{array}{l}39 \\
43 \\
54 \\
51 \\
53 \\
36 \\
41\end{array}$ \\
\hline $\begin{array}{l}\text { EXTRAVERSION } \\
\text { E1)Warmíh } \\
\text { E2)Gregariousness } \\
\text { E3)Assertiveness } \\
\text { E4)Activity } \\
\text { E5)Excitement-seeking } \\
\text { E6)Positive Emotions }\end{array}$ & $\begin{array}{r}121.7 \\
23.6 \\
17.3 \\
18.8 \\
19.0 \\
21.6 \\
21.5\end{array}$ & $\begin{array}{r}16.8 \\
4.1 \\
4.5 \\
4.1 \\
3.9 \\
4.3 \\
4.2\end{array}$ & $\begin{array}{r}124.5 \\
24.5 \\
17.9 \\
19.0 \\
19.8 \\
20.3 \\
23.1\end{array}$ & $\begin{array}{r}17.0 \\
3.9 \\
4.6 \\
4.7 \\
4.3 \\
4.6 \\
4.0\end{array}$ & $\begin{array}{l}-2.44 \\
-2.44 \\
-1.94 \\
-0.68 \\
-2.92 \\
4.34 \\
-5.67^{* * *}\end{array}$ & $\begin{array}{l}33 \\
38 \\
42 \\
47 \\
39 \\
67 \\
29\end{array}$ \\
\hline $\begin{array}{l}\text { OPENNESS } \\
\text { O1)Fantasy } \\
\text { O2)Aesthetics } \\
\text { O3)Feeings } \\
\text { O4)Actions } \\
\text { O5)Ideas } \\
\text { O6)Values }\end{array}$ & $\begin{array}{r}113.0 \\
17.3 \\
15.8 \\
20.7 \\
16.1 \\
22.0 \\
21.2\end{array}$ & $\begin{array}{r}15.8 \\
4.7 \\
5.7 \\
4.0 \\
3.5 \\
4.6 \\
4.4\end{array}$ & $\begin{array}{r}118.2 \\
17.2 \\
17.8 \\
22.5 \\
17.2 \\
21.3 \\
22.3\end{array}$ & $\begin{array}{r}15.8 \\
5.0 \\
5.2 \\
3.8 \\
3.7 \\
4.7 \\
3.8\end{array}$ & $\begin{array}{c}-4.83^{\ldots *} \\
0.31 \\
-5.28^{\ldots *} \\
-6.70^{\ldots *} \\
-4.53^{\ldots *} \\
2.22 \\
-3.82 \ldots\end{array}$ & $\begin{array}{l}18 \\
51 \\
28 \\
26 \\
34 \\
41 \\
35\end{array}$ \\
\hline AGREEABLENESS & 48.3 & 7.0 & 51.0 & 6.6 & $-5.76^{* * *}$ & 23 \\
\hline CONSCIENTIOUSNESS & $5 \simeq .9$ & 8.0 & 55.2 & 7.6 & $-4.28^{\circ * *}$ & 28 \\
\hline
\end{tabular}


scores on the Aestheticsfacet than would adult wornen. In contrast, woinen controllers differed significantly from college women on 4 of the $6 O$ facet scales. Women controllers were more likely to have lower scores than college women on the Faniasy, Aesthetics, and Feelings facets, and higher scores on the Ideas facet. Overall, the pattern of overlap and effect sizes suggested that women controllers were more similar to ajult women on the first three facets (Fantasy, Aesthetics, and Feelings) and more similar to college women on the Actions, Ideas, and Values facets.

\section{Comparison of Men and Worgen Controllers}

Means and standard deviations fo. the NEO-PI domain and facer scales for men and women ATCS students are presented in Table 15. While there was some degree of overlap tetween the sexes, the $t$ tests and $C L$ effect sizes revealed that men and women differed significantly and practically on 3 of the 5 domain scales. Women ATCSs had higher scores than men on the $O, A$, and $C$ domain scales $(p \leq .004)$. The higher $O$ scores for women ATCS students were consistent with sex differences reported by Costa and McCrae (1989). Averages for women were also higher than men on the $N$ and $E$ domain scales, but did not meet the practical cutoff of $25 \leq C L \geq 75$. None of the differences noted on the facet scales between men and women met the stipulated cutoff for practical significance, al though there were several statistically significant differences of interest. For example, men were less impulsive (N5) and reported less positive emotions (E6) than women controllers ( $p \leq .004)$, but sought more excitement (ES). Women had higher scores, on the average, than men controllers on 4 of the 6 Opennessfacet scales: Aesthetics (O2), Feelings (O3), Actions (O4), and Values (O6). Overall, men and women entry-level controllers appeared to have quite similar profiles, with women generally having just slightly elevated scores over men.

\section{Correlations}

\section{Prediction of Performance}

Zero order correlations berween the measure of cognitive aptitude (RATING) for the ATCS occupation, NEO-PI facet and domain scale scores, and final composite score (COMP) in the screen for both men $(N=529)$ and women $(N=193$ ) cases with complete valid data are presented in Tables 16 and 17. Correlations between aptitude (RATING) and personality scores for men ranged from a low of .000 with Impulsive (N5) to an absolute maximum of .098 with the Ideas $(\mathrm{O} 5)$ facet. Correlations between aptitude and personality scores for women were similarly low, ranging from .002 with Fantasy $(\mathrm{O} 1)$ to a high of .169 with Values (O6). Correlations berween the personality measures and Academy screen score (COMP) for men were also low, ranging from - .005 for Aesthetics (O2) to -.148 with the facet Excitement-seeking(ES). The pattern of correlations between personality and performance for women was very similar, with generally low correlations ranging from -.005 with Assertiveness (E3) to .178 with Ideas (O5).

\section{Regression}

Results of the regression analysis to determine if the personality variables contributed to the prediction of Academy Screen performance above that contributed by cognitive aptitude are presented in Table 18 by sex. The results suggested that the null hypothesis should be rejected for both men and women controllers. There was a small, but signifcant increase in incremental validity for men when personality variables entered the prediction equation $\left(\Delta R^{2}=.033\right.$, $\Delta F(4,524)=3.84, p \leq .05)$. The significant personality factors included the Fantasy (01), Excitement-seeking (E5), and Astivity (E4) facets. However, the total percentage of explained variance that those three variables added was quite small (3\%). Just one facet, Ideas (O5), entered the stepwise regression solution for women, after entering aptitude into the prediction equation $\left(\Delta R^{2}=.028, \Delta F(2,190)=5.53, p\right.$ $\leq .05)$. As with men, personality accounted for a bare $3 \%$ of additional explained variance in performance above that already explained by cognitive aptitude. 


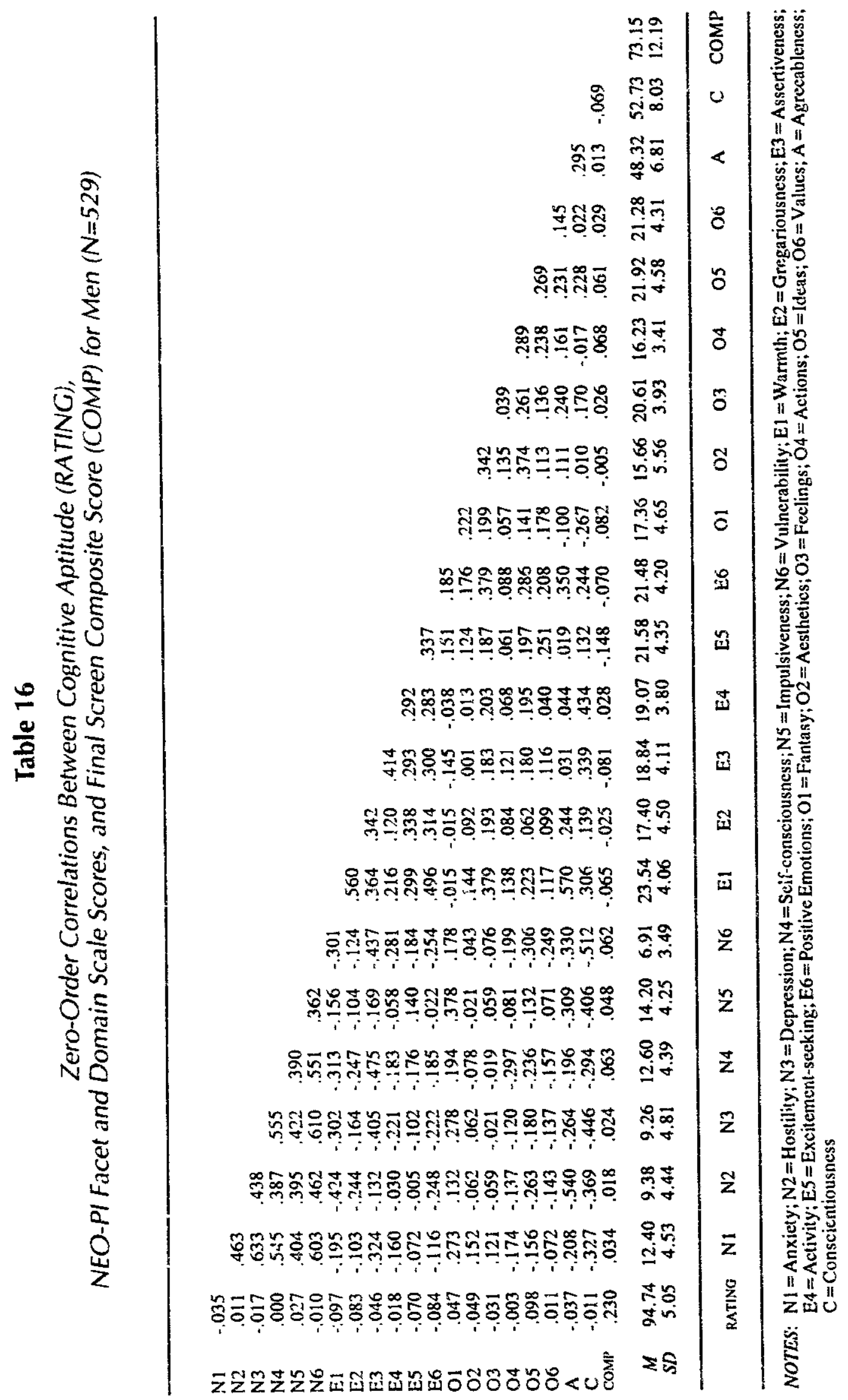




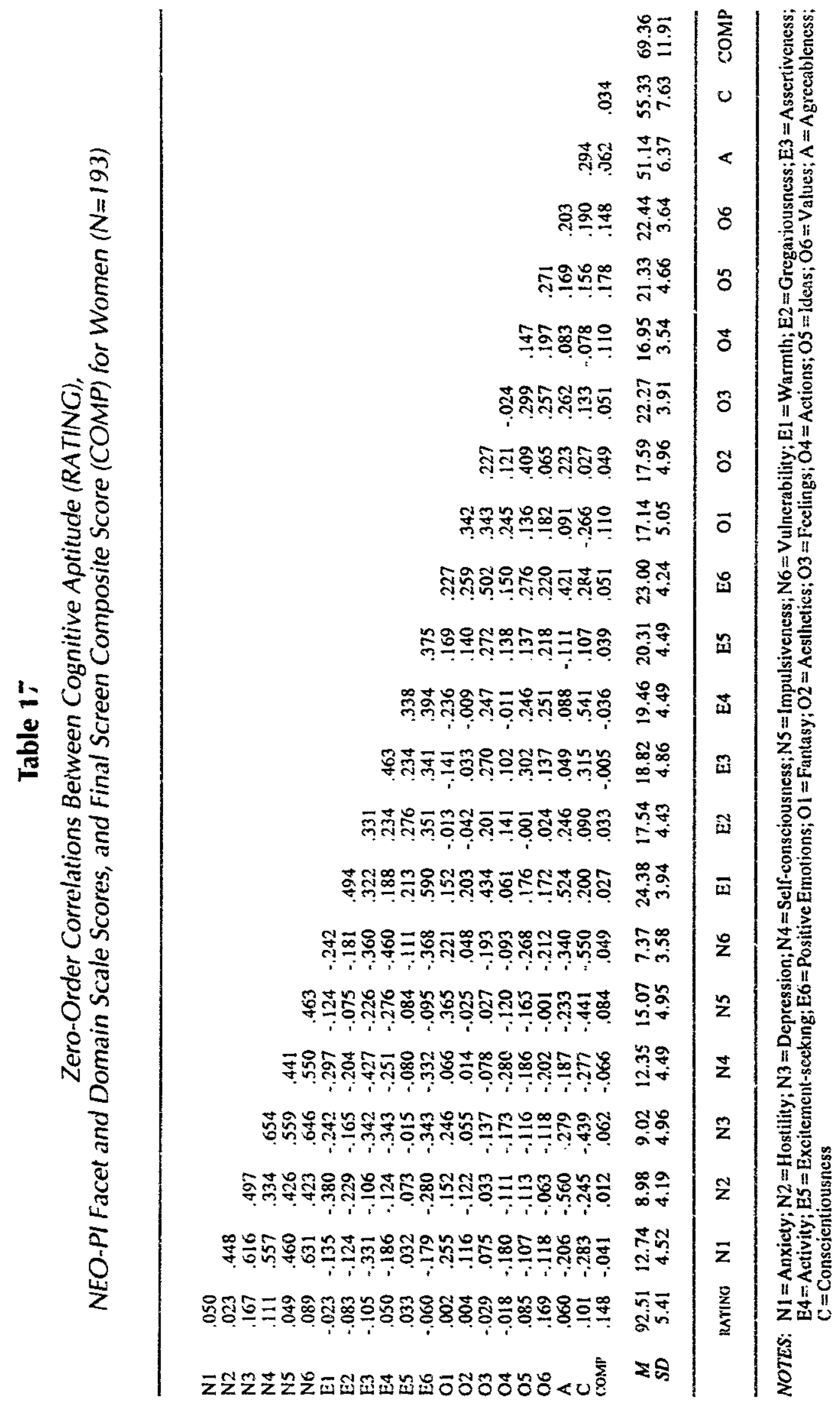


Table 18

Regression Analysis of incremental Validity of Personality Over Aptitude in Prediction of ATCS Screen Performance by Sex

\begin{tabular}{|c|c|c|c|c|c|c|c|c|}
\hline Step & Var & $\beta$ & $R$ & $\hat{K}$ & Adj $-R^{2}$ & $\Delta R^{2}$ & $\Delta F$ & $\stackrel{F}{(d f)}$ \\
\hline \multicolumn{9}{|c|}{ Men } \\
\hline 1 & RATING ${ }^{1}$ & .230 & .230 & .053 & .051 & & & $\begin{array}{r}29.34 \cdots \\
(1,527)\end{array}$ \\
\hline 2 & $\underset{\mathrm{ES}^{2}}{\text { RATING }}$ & $\begin{array}{r}.220 \\
-.132\end{array}$ & .265 & .070 & .067 & .017 & $9.86^{* *}$ & $\begin{array}{c}19.85^{* \cdots} \\
(2,526)\end{array}$ \\
\hline 3 & $\begin{array}{c}\text { RATIiJG } \\
\text { ES } \\
\text { O1 }\end{array}$ & $\begin{array}{r}.215 \\
-.147 \\
.094\end{array}$ & .281 & .079 & .074 & .009 & $4.92^{\circ}$ & $\begin{array}{c}14.97^{\circ-} \\
(3,525)\end{array}$ \\
\hline \multirow[t]{2}{*}{4} & $\begin{array}{c}\text { RATING } \\
\text { ES } \\
\text { OI } \\
\text { E4 }\end{array}$ & $\begin{array}{r}.214 \\
-.173 \\
.101 \\
.086\end{array}$ & .292 & .086 & .079 & .007 & $3.84^{\circ}$ & $\begin{array}{c}12.25^{\circ} \\
(4,524)\end{array}$ \\
\hline & \multicolumn{8}{|c|}{ Women } \\
\hline 1 & RATING & .148 & .148 & .022 & .017 & & & $\begin{array}{l}4.25^{\circ} \\
(1,191)\end{array}$ \\
\hline 2 & $\begin{array}{l}\text { RATING } \\
\text { O5 }\end{array}$ & $\begin{array}{l}.133 \\
.167\end{array}$ & .222 & .049 & .039 & .028 & $5.53^{\circ}$ & $\begin{array}{l}4.94^{*} \\
(2,190)\end{array}$ \\
\hline NOTES: & $\begin{array}{l}{ }^{2} \text { RATING } \\
{ }^{2} \text { E5 }=\text { Excit } \\
\text { O1 = Fant } \\
\text { O5 = Ideas } \\
\text { E4 = Activ }\end{array}$ & $\begin{array}{l}\text { ente } \\
\text { nent-s } \\
y\end{array}$ & ng; & & $p$ & .05 & $\leq .01$ & $p \leq .60$ \\
\hline
\end{tabular}




\section{DISCUSSION}

\section{Differences Between Controllers and General Population}

Practical versus statistical significance. Overall, most of the comparisons between entry-level controllers of borh sexes to their respective adult and college normative samples were statistically different. However, the relatively large sample sizes provided a great deal of statistical power, such that even very small, practically insignificart differences could be reliably detected. In this study, Tilton's $O(1937)$ and the Common Language Effect Size (CL: McGraw \& Wong. 1992) were employed to evaluate the practical magnitude of any detected statistical differences. Of the two, $C L$ appeared to provide a more parsimonious description of differences by describing the number of occasions certain differences were likely to be observed in a random pairing of 100 cases from each sample. In general, the patterns of $t$ test revulis combined with the overlap and effect size estimates indicated that women entry-level controllers were lower in neuroticism and higher on extraversion and conscientiousness than either the adult or college women normative groups, and that these differences were practically as well as statistically significant. Differences between men entry-level controllers and adult men were generally similar to those noted for women. Men controllers were expected to have higher $C$ scores than adult men in 78 of 100 random painings; in comparison, controllers were expected to have higher $E$ scores in 99 of 100 pairings compared to a higher $N$ score in only 9 of 100 such pairings. Entry-level men controllers were lower in neuroticism, openness to experience, and conscientiousness than college men. For example, men ATCSs were expected to have higher conscientiousness than college men in just 2 of 100 pairings, indicating that the statistical difference between men controllers and college men on the $C$ domain was practically significant.

\section{Profile interpretation}

Given these apparent differences between controllers and normative samples, how would men and women controllers be described on the basis of the NEO-PI profile? Overall, ATCSs scored in the low-average range of the Neuroticism domain. Similar individuals might be seen as being generally calm and able to deal with stress; however, they would still experience a normal amount of disappointment and anger. The ATCS group, as a whole, had scores in the upper-range of the Extraversion domain. Individuals with these scores are cheerful, generally satisfied with life, and prefer excitement and stimulation along with the company of others most of the time. The Openness to Experience scores for these entry-level controllers suggested that they could be chatacterized as having broad interests, knowledgeable about many topics, and as being intellectually curious or investigative. The distribution of scores in the Agreeableness domain hinted that some ATCSs present themselves as generally warm, trusting, agreeable, and sympathetic to others while others present themselves as more toughminded, skeptical, and competitive. ATCS group scores in the Conscientiousness domain were also in the midrange. $S$ : : h scores suggest that the entry-level controllers exhibit an average level of determination, reliability, and self-direction. Overall, the pattern of scores for men and women controliers suggested a certain level of intensity, energy, ambition or purpose, gregariousness, and generally good adjustment within this sample of controllers. Women entry-level controllers, in particular, appeared to be more dominarit and forceful tnan their normative peers.

\section{Conclusions about Differences Between Controllers and General Population}

Persons who enter the FAA Academy ATCS Nonradar Screen program do differ from coilege students and adults on a number of personality dimensions as assessed by the NEO-PI. Differences were found generally on domain scales, with those differences being traced in some cases to specific facets within a domain. Those differences were similar for men and women controllers; controllers were more outgoing and had higher-levels of excitement-seeking, expressed more positive emotions, and were more conscientious than the normative samples.

Some of the differences noted above, however, may be attributable to the tendency for job applicants and employees undergoing evaluations to present themselves in a positive light. Previous research with the $16 \mathrm{PF}$ and ATCS applicants and job incumbents supports the presence of positive self-presentation (Karson \& O'Dell, 1974; Schroeder \& Dollar, 1989). However, the 
differences between ATCS students and the normative groups were not evident across each of the dimensions or facets of the NEO-PI that one would expect to be sensitive to a positive test-taking attitude (e.g., Agreeableness).

\section{Utility of Personality Measures}

Selected aspects of personality aiso demonstrated incremental validity over cognirive measures in the prediction of performance in the FAA Academy ATCS Nonradat Screen program. Two of three facets that contributed to the final regression equation were $d$; 2 nn from the Openness to Experience domain. That finding is consistent with Barrick and Mount's (1991) conclusion that scores from the Odomain were likely to be related to performance in training.

While the absolute amount of additional variance explained was small (2\%), such marginal gains have significant utility impacts in large-scale selection systems such as that for controllers. For example, the increase in the proportion of employees considered satisfactory from the use of aptitude plus personality measures can be estimated using the Taylor-Russell tables (Taylor \& Russell, 1939). Overall, about $60 \%$ of persons entering the Screen were successful. The current selection ratio, based on the cognitive aptirude ratings, is about .10. The validity coefficient of the cognitive aptitude rating by itself for this sample of men was about .23, and for women, .15 . The validity coefficient for the combined group was .23 . About $74 \%$ of the combined sample of men and women entry-level controllers would have been predicted to succeed in the Screen, based on interpolation of the Taylor-Russell tables. The validity coefficient for the cognitive aptitude rating plus personality facets was .29 for men and .22 for women, or about .27 for the combined sample. The interpolated predicted success rate for men and women would have bcen $77 \%$ if the NEO-PI scores had been used with cognitive aptitude scores in selecting persons to attend the FAA Academy. Overall, use of a combined personality-aptitude selection procedure would have resulted in net gain of about $3 \%$ in prediccive efficiency, or approximately 30 additional developmental controllers (out of every 1000) being available to the FAA for field training.
The impact of that gain of 30 developmental controllers from a sample of about 1,000 entry-level controllets may not seem significant until placed in the context of the relative costs to the agency. The FAA Academy ATCS Nonradar Screen cost approximately $\$ 10,000$ per student to administer (Aerospace Sciences, Inc., 1991). With about 2,000 candidates entering the FAA Academy each year, reduction of the failure rate by 30 controllers per 1000 candidates would have resulted in a savings of $\$ 600,000$ per year in terms of wasted training resources. The total savings over the 5 full years of the ATCS Nonradar Screen's operational life would have been on the order of $\$ 3$ Million in saved training resources. In other words, implementation of an ATCS selection test procedure with just marginal improvements in validity would have resulted in a significant savings to the agency.

\section{Future Research Needs}

The results presented in this paper - rovide some empirical counterpoints to the claim by Besco (1991) that personality measurement in selection programs for professional performance lack borh scientific and practical value. Additional research is needed to provide further validation of these outcomes. Differences between entry-level controllers and the general population norms were found, with controllers being overall less neurotic, more extraverted and conscientious. Entry-level contro!lers reported few neurotic symptoms, appcared to exhibit better adjustment, and tended to be outgoing individuals with higher levels of excitement-seeking and more expressive of positive emotions. This provides a generally positive picture of those who apply and are selected to become operational controllers, and also suggests that they are wel! suited for handling the demands of a highly responsible job. These differences were in keeping with lay perceptions of the "controller personality," and supportive of research that suggests that certain occupations may attract individuals with different personality characteristics (Kassera \& Russo, 1987). Additional research might investigate the relationships between personality and biodemographic factors, such as reasons for occupational choice and career expectations in the controller occupation. 
Such research could provide the foundation for ATCS career guidance tools for use by aviation educators and agency recruiters.

The findings reported in this paper demonsirate that personality, as represented by scores on a theoreticallybased and psychometrically sound instrument, explained additional variance in a technical performance measure beyond that explained by cognitive aptitude. It must be noted that this performance measure appeared to be uncontaminated by evaluative biases noted by Besco as fatal flaws in personality-oriented research. However, further research is needed to identify which aspects of the Screen program are most influenced by personality, such as the Instructor Assessment of student potential. While the observed relationships were small, it must be noted that our sample was a highly select group. Selection on the cognitive aptitude rating likely resulted in incidental restriction in the range of personality scores. It is probable that if the group were nor initially selected or. the basis of cognitive abilities, we would see a higher relationship between the NEO-PI scores and performance in the FAA Academy ATCS Nonradar Screen. In addition, further research is warranted on the interaction between personality and aptitude in performance to test the hypothesis that certain personality attributes may enhance or detract from performance for persons with high or low aptitude for the occupation. Finally, longitudinal research assessing the uillity of personality measures in predicting performance across time is required. It is likely that the relationships between performance and stable personality traits change over time. The initial predictive power of personality dimensions may be low due to two factors: (a) variance in initial performance may be accounted for by ability and prior experience; and (b) as the "honeymoon", characterized by initially high commitment and effort, ends in a new job, the novelty and challenge in a job may fade and dispositional facturs may become increasingly important determinants of performance (Helmreich, Sawin, \& Carsrud, 1986). Both of these factors may account, at least in part, for the seemingly low observed personality-performance relations. Long-term follow-up studies will enable us to investigate changes in the personality-performance relations within the controller occupation.

\section{References}

Aerospace Sciences, Inc. (1991). Ait traffic control specialist Pre-Training Screen preliminary validation: Final report. (Final report delivered to FAA under contract DFA01-90-Y-01034). Washington, DC: Federal Aviation Administration Office of the Deputy Administrator.

Aul, J. C. (1991). Employing air traffic controllers. In H. Wing, \& C. A. Manning (Eds.). Selection of air traffic controllers: Complexity, requirements, and public interest. (DOT/FAA/AM-91/9). Washington, DC: Federal Aviation Administration Office of Aviation Medicine.

Barrick, M. R., \& Mount, M. K. (1991). The Big Five personality dimensions and job performance: $A$ meta-analysis. Personnel Psychology, 44, 1-26.

Besco, R. O. (1991). The myths of pilot personality stereotypes. Paper presented at the Gth International Symposium on Aviation Psychology, Columbus, $\mathrm{OH}$.

Boone, J. O. (1979). Toward the development of a new selection battery for air traffic control specialists. (DOT/FAA/AM-79/21). Washington, DC: Federal Aviation Administration Office of Aviation Medicine. [NTIS AD A080 065].

Buckley, E. P., O'Connor, W. F. \& Beebe, T. (1969). A comparative analysis of individual and system performance indices for the air traffic control system. Atlantic City, NJ: Federal Aviation Administration National Aviation Facility Engineering Center (NAFEC).

Cascio, W. F. (1984). Costing human resources: The financial impact of behavior in organizations. Boston, MA: Kent Publishing Co.

Cattell, R. B., Eber, H. W., \& Tatsuoka, M. M. (1970). Handbook for the 16PF. Champaign, IL: Institute for Personality and Aptitude Testing (IPAT).

Collins, W. E., Nye, L. G., \& Mannirig, C. A. (1990). Studies of poststrike air traffic control specialist trainees: III. Changes in demographic characteristics of Academy entrants and biodemographic predictors of success in air traffic controller selection and Academy screening. (DOT/FAA/AM-90/4). Washington, DC: Federal Aviation Administration Office of Aviation Medicine. 
Collins, W. E., Schroeder, D. J., \& Nye, L. G. (1989). Relaxionships of anxiety scores to Academy and field training performance of air traffic control specialists. (DOT/FAA/AM-89/7). Washington, DC: Federal Aviation Administration Office of Aviation Medicine.

Colman, J. G. (1970). Review and evaluation of present system for selection of air traffic controllers. (Phase $\mathrm{I}$, Task I Report submitted under Contract No. DOT-FA70WA-2371.) Washington, DC: Educacion and Public Affairs, Inc.

Costa, P. T. Jr., \& McCrae, R. R. (1980). Still stable after all these years: Personality as a key to some issues in adulthood and old age. In P. Baltes \& $O$. G. Brim, Jr. (Eds.). Lifespan, development and behavior. New York: Academic Press.

Costa, P. T. Jr., \& McCrae, R. R. (1985). The NEO Personality Inventory manual Odessa, FL: Psychological Assessment Resources.

Costa, P. T. Jr., \& McCrae, R. R. (1988a). Personality in adulthood: A six-year longitudinal study of selfreports and spouse ratings on the NEO Personality Inventory. Journal of Personality and Social Psychology. 54. 853-863.

Costa, P. T. Jr., \& McCrae, R. R. (1988b). NEO-PI/FFI Manual supplement. Odessa, FL: Psychologica! Assessment Resources.

Costa, P. T., Jr., McCrae, R. R., \& Holland, J. L. (1984). Personality and vocational interests in an adult sample. Journal of Applied Psychology, 69, 390-400.

Della Rocco, P. S., Manning, C. A., \& Wing, H. (1990). Selection of air traffic controllers for automated systems: Applications from current research. (DOT/FAA/AM-90/13). Washington, DC: Federal Aviation Administration Office of Aviation Medicine. [NTIS AD A238 267].

Dolgin, D. L., \& Gibb, G. D. (1989). Personaliry assessment in aviator selection. In $\mathrm{R}$. S. Jensen (Ed). Aviation psychology, p. 288-320. Brookfield, VT: Gower.
Deloney, J. R., \& Schroeder, D. J. (1983). Ways of perceiving the world and the relationship to success among air traffic controilers. Presented at the 54 th Annual Scientific Meering of the Aerospace Medical Association, Houston, TX.

Eissfeldt, H. (1990). The DLR selection of air traffic control applicants. German Aerospace Research Establishment DLR, Hamburg, Germany.

Gough, H. G. (1960). Manz:al for the California Psychological Inventory. (Rev. Ed.). Palo Alto, CA: Consulting Psychologists Press.

Guion, R. M., \& Gibson, W. M. (1988). Personnel selection and placement. Annual Review of Psychology, 39, 349-374.

Guion, R. M. \& Gottier, R. F. (1965). Validity of personalicy measures in personnel selection. Personnel Pyychology, 18, 349-374.

Helmreich, R. L., Sawin, L. L., \& Carsrud, A. L. (1986). The honeymoon effect in job performance: Temporal increases in the predictive power of achievement motivation. Joumal of Applied Psychology, $71,185-188$.

Hofstee, W. (1984). What's in a trait: Reflections about the inevitability of traits, their measurement, and taxonomy. In H. Bonarius, G. Van Heck, \& N. Smid, (Eds.). Personality psychology in Europe: Theoretical and empirical developments. Lisse, the Netherlands: Swets \& Zeitlinger.

Hogan, R. T. (1983). A socioanalytic theory of personality. In M. Page, (Ed.). Nebraska Symposium on Motivation, 55-89. Lincoln, NE: University of Nebraska Press.John, O. P., Angleitner, A., \& Ostendorf, F. (1988). The lexical approach to personality: A historical review of trait taxonomic research. European Journal of Personality, 2, 171203.

Karson, S., \& O'Dell, J. W. (1969), A criterion factor analysis of performance ratings and personality factors in radar controllers. Paper presented at the Annual Scientific Meeting of the Aerospace Medical Association, San Francisco, CA.

Kassera, W., \& Russo, T. (1987). Factor analysis of personality oreferences and vocational interest. Psychological Reports, 60, 63-66. 
Manning, C. A., Della Rocco, P. S., \& Bryanc, K. D. (1989). Prediction of success in FAA air traffic control field training as a function of selection and screening test performance. (DOT/FAA/AM-89/6). Washington, DC: Federal Aviation Administration Office of Aviation Medicine. [NTIS AD A209 327/6/XAB].

Manning, C. A., Kegg, P. S., \& Collins, W. E. (1989). Selection and screening programs for air traffic control. In R. S. Jensen (Ed.), Aviation psychology, 321-341. Brookfield, MA: Gower Technical.

Manning, C. A., VanDeventer, A. D., \& Baxter, N. E. (1984). Sensation seeking and performance in air traffic control specialist training. Presented at the 55th Annual Scientific Meeting of the Aerospace Medical Association, San Diego, CA.

McCrae, R. R., \& Costa, P. T. Jr. (1987). Validation of the five-factor model of personality across instruments and observers. Journal of Personality and Social Psychology, 52, 81-90.

McGraw, K. O., \& Wong, S. P. (1992). A common language effect size statistic. Psychological Bulletin, $111,361-365$.

Myers, I. B. (1962). The Myers-Briggs Type Indicator. Palo Alto, CA: Consulting Psychologists Press.

Naylor, J. C., \& Shine, L. C. (1965). A table for determining the increase in mean criterion score obtained using a selection device. Journal of Industrial Psychology, 3. 33-42.

Norman, W. (1963). Toward an adequate taxonomy of personality attributes. Journal of Abnormal and Social Psychology, 66, 574-583.

Nye, L. G., \& Collins, W. E. (1991). Some personality characteristics of air traffic control specialist trainees: Interactions of personality and aptitude test scores with FAA Academy success and career expectations. (DOT/FAA/AM-91/8). Washington, DC: Federal Aviation Administration Office of Aviation Medicine.

Nyfield, G. R., Kandola, R. S., \& Saville, P. F. (1983). The Selection of air traffic controllers: Concurrent validity study. London, England: 5aville and Holdsworth Ltd.
Reilly, R. R., \& Chao, G. T. (1982). Validity and fairness of some alternative employee selection procedures. Personnel Psychology, 35, 1-62.

Rock, D. B., Dailey, J. T., Ozur, H., Boone, J. O., \& Pickerel, E. W. (1982). Selection of applicants for the air traffic controller occupation. (DOT/FAA/ AM-82/11). Washington, DC: Federal Aviation Administration Office of Aviation Medicine. [NTIS AD A122 795/8].

Rosenthal, R., \& Rubin, D. B. (1984). Multiple contrasts and ordered Bonferonni procedures. Journal of Educational Psychology, 76, 1028-1034.

Schroeder, D. J. (1984). Cognitive style and ATCS Academy pass/fail status. Presented at the 55th Annual Scientific Meeting of the Aerospace Medical Association, San Diego, CA.

Schroeder, D. J., \& Dollar, C. S. (1989). Personality characteristics of prelpost-strike air traffic control applicants. Presented at the 60th Annual Scientific Meeting of the Aerospace Medical Association, Washington, DC.

Seigel, A. I. (1978). Miniature job training and evaluation as a selection/ classification device. Human Factors, 20, 189-200.

Seigel, A. I. (1983). The miniature job training and evaiuation approach: Additional findings. Personnel Psychology, 36, 41-56.

Seigel, A. I., \& Bergman, B. A. (1975). A job learning approach to performance predictio'. Personnel Psychology, 28, 325-339.

Sells, S. B., Dailey, J. T., \& Pickrel, E. W. (Eds.) (1984). Selection of air traffic controllers. (DOT/FAA/ AM-84/2). Washington, DC: Federal Aviation Administration Office of Aviation Medicine. [NTIS AD A147 765].

Smith, R. C. (1985). Stress, anxiety and the air traffic control specialist: Some surprising conclusions from a decade of research. In C. D. Spielberger \& I. G. Sarason (Eds.). Stress and Anxiety. (Vol. 9, pp. $95-$ 100). New York: Hemisphere.

Spielberger, D. C. (1979). Preliminary manual for the State-Trait Personality Inventory. Tampa, FL: University of South Florida, Human Resources Institute. SPSS, Inc. (1990). SPSS reference guide. Chicago, IL: Author. 
Taylor, H. C., \& Russell, J. T. (1939). The relationship of validity coefficients to the practical effectiveness of tests in selection: Discussion and tables. Journal of Applied Psychology, 23, 565-578.

Tett, R. P., Jackson, D. N., \& Rothstein, M. (1991). Personality measures as predictors of job performance: A meta-analytic review. Personnel Psychology, 44, 703-742.

Tenopyr, M. L., \& Oeltien, P. D. (1982). Personnel selection and classification. Annual Review of Psychology, 33, 581-618.

Tilton, J. W. (1937). The measurement of overlapping. Journal of Educational Psychology, 28, 656-662.
Trites, D. K., Kurek, A., \& Cobb, B. (1967). Personality and achievement of air traffic controllers. Aerospace Medicine, 38, 1145-1150.

Tupes, E. \& Christal, R. (1961). Recurrent personality factors based on truit ratings. (Technical Report No. 61-97). Lackland AFB, TX: U.S. Air Force Aeronautical Systems Division.

United States Congress. (January 20, 1976). House Committee on Government $O$ perations recommendations on air traffic control training. Washington, $D C$ : Author.

Zuckerman, M. (1979). Sensation seeking: Beyond the optimal level of arousal. Hillsdale, NJ: Erlbaum. 